\title{
Hyperoestrogenisme bij een vrouwelijke chihuahuapup
}

\author{
Hyperestrogenism in a female Chihuahua puppy
}

\author{
${ }^{1}$ J. De Loor, ${ }^{1}$ A. Van Soom \\ ${ }^{1}$ Vakgroep Voortplanting, Verloskunde en Bedrijfsdiergeneeskunde \\ Faculteit Diergeneeskunde, UGent, Salisburylaan 133, B-9820 Merelbeke \\ jorien.deloor@skynet.be
}

\begin{abstract}
SAMENVATTING
Een vrouwelijke intacte chihuahuapup van vier maanden oud werd aangeboden met als klacht vulvazwelling en seksueel rijgedrag op een speelgoedbeer. Beide klachten waren reeds aanwezig vanaf 9-10 weken ouderdom. Tijdens het consult viel op dat de pup ook sterk opgezette melkklieren vertoonde. De volgende differentiaaldiagnose werd vooropgesteld: gonadotropineonafhankelijke (perifere) vroegtijdige puberteit (of vroegtijdige pseudopuberteit) ten gevolge van een exogene opname van oestrogenen, ofwel interseksualiteit. De eerste mogelijkheid leek het meest waarschijnlijk gezien de eigenares het gezicht en de schouders dagelijks met oestrogenengel insmeerde. Er werd aangeraden om het contact van de pup met de oestrogenengel te vermijden. Deze behandeling leverde gunstige resultaten op na een periode van twee maanden, met zelfs het compleet verdwijnen van de klachten vier maanden na het initiële consult.
\end{abstract}

\begin{abstract}
A female intact Chihuahua pup was presented at the age of four months with complaints of vulvar swelling and precocious sexual behaviour. Both complaints started to develop at the age of 9-10 weeks. During clinical examination, inspection revealed swollen mammary glands. The differential diagnosis was gonadotrophinindependent (peripheral) precocious puberty (or precocious pseudopuberty) as a result of the exogenous intake of estrogens, or intersexuality. The first diagnosis was the most probable one since the female owner of the dog applied an estrogen gel on face and shoulders on a daily basis. The owner was advised to avoid contact of the pup with the gel. This resulted in a positive evaluation after two months, with a complete disappearance of the complaints four months after the first examination.
\end{abstract}

\section{INLEIDING}

\section{Het optreden van de eerste loopsheid}

Bij een seksueel immature teef zijn oestrische cycli afwezig. De specifieke klinische tekenen van de oestrische cyclus bij de hond worden normaal niet geobserveerd bij een prepuberale teef (Rehm et al., 2007). Tijdens de puberteit verwerven honden de mogelijkheid om zich voort te planten (Johnston et al., 2001). Bij de teef wordt deze periode gekenmerkt door het optreden van de eerste loopsheid met een aantal duidelijke fysische en gedragsveranderingen. Tijdens de pro-oestrus, i.e. de eerste fase van de loopsheid, is er een zwelling van de vulvalippen in combinatie met serohemorragische vaginale uitvloeiing. De teef reageert eerst agressief tegenover geïnteresseerde reuen die de nabijheid van de teef detecteren via seksferomonen in haar vaginaal secreet. (In een studie werd methyl-p-hydroxybenzoaat geïdentificeerd als seksferomoon in vaginale secreties van loopse teven (Concannon, 2011)). Naarmate de pro-oestrus vordert, wordt deze reactie steeds speelser. Pas tijdens de tweede fase van de loopsheid, i.e. de oestrus, wordt de teef seksueel receptief en kan de dekking plaatsvinden. Het oedeem van de vulvalippen en de serohemorragische vaginale uitvloeiing nemen geleidelijk aan af (Johnston et al., 2001; Concannon, 2011).

In de hypothalamus van vrouwelijke zoogdieren onderscheidt men twee GnRH release generators: de tonische release generator - ook de puls generator genoemd - en de cyclische of fasische release generator of de piekgenerator (Maeda et al., 2010) (Figuur 1B). Een interne klok bepaalt ongeveer het tijdstip van het optreden van de puberteit, i.e. het tijdstip waarop deze generatoren de eerste oestrische cyclus induceren. Interne en externe factoren verfijnen dit tijdstip. Deze permissieve factoren bepalen dus wanneer het puberteitsalarm precies afgaat. Geschikte combinaties van de permissieve factoren laten toe dat de puberteit start, i.e. als het lichaam voldoende gegroeid is, genoeg energie ter beschikking heeft en als het seizoen geschikt is voor reproductie (bij seizoenkwekers) (Sisk en Foster, 2004) (Figuur 1A). Wanneer dit gebeurt, leiden gecoördineerde veranderingen in excitatorische en inhibitorische inputs (neuronaal en gliaal) naar de GnRH- 


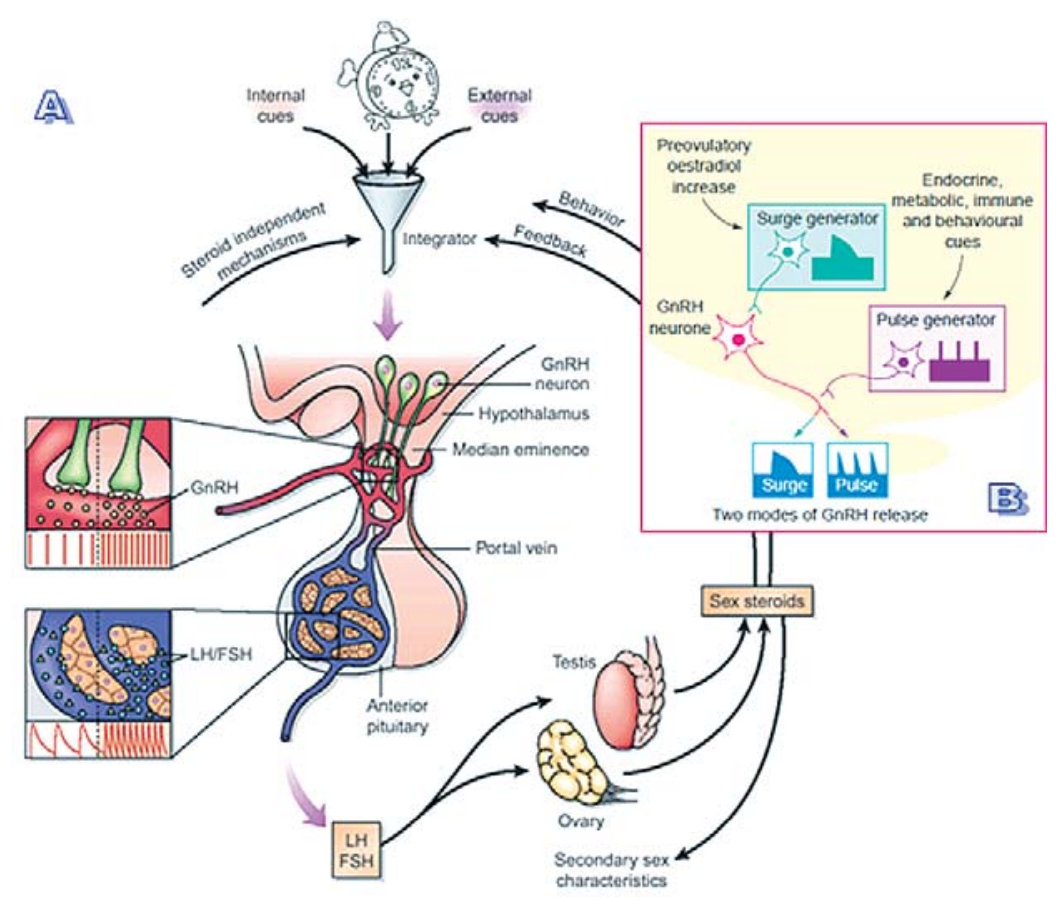

Figuur 1. Neuro-endocriene, fysische en gedragsveranderingen tijdens de puberteit (Naar Nishihara et al., 1999; Sisk en Foster, 2004). A. start puberteit: de integratie van kloksignalen en diersoortspecifieke permissieve signalen leidt tot gecoördineerde veranderingen in excitatorische en inhibitorische inputs naar de GnRH-neuronen (steroïdonafhankelijk o.a. mens of steroïdafhankelijk o.a. schaap); er is een toename van de pulsatiliteit van de GnRH-vrijstelling (gedefinieerd als de start van de puberteit) en dit resulteert in een toegenomen oestradiolproductie met het ontstaan van secundaire geslachtskenmerken en seksueel gedrag. Veranderingen in evenwicht, hiërarchie en de interactie tussen permissieve signalen drijven de verdere maturatie (of disinhibitie). B. einde puberteit: de oestradiolconcentratie bereikt de drempelwaarde die nodig is voor de stimulatie van de piekgenerator (positieve feedback); de eerste LH-piek treedt op en duidt het einde aan van de puberteit. neuronen (steroïdonafhankelijk o.a. mens of steroïdafhankelijk o.a. schaap - mechanisme bij de hond nog onbekend (Sisk en Foster, 2004)) tot een toename van de pulsatiliteit van de GnRH-vrijstelling met de ontwikkeling van secundaire geslachtskenmerken tot gevolg (oestradioleffect) (Terasawa en Fernandez, 2001) (Figuur 1A). Veranderingen in evenwicht, hiërarchie en de interactie tussen permissieve factoren drijven de verdere maturatie (of disinhibitie) (Sisk en Foster, 2004). Het bereiken van $85 \%$ van het volwassen lichaamsgewicht (Linde-Forsberg, 2001) wordt gezien als een belangrijk permissief signaal en initieert bij de teef waarschijnlijk de finale maturatie van het neuron- en glianetwerk (steroïdafhankelijk o.a. mens) (Sisk en Foster, 2004). De oestradiolconcentratie stijgt en bereikt de kritische drempelwaarde die nodig is voor de stimulatie van de piekgenerator (Maeda et al., 2010). De resulterende GnRH-piek vertaalt zich vooral in een hoge LH-piek, maar deze eerste oestrus is meestal anovulatoir (Terasawa en Fernandez, 2001) (Figuur 1B).

Voor teven van miniatuurrassen treedt de eerste loopsheid op tussen 6 en 10 maanden ouderdom. Bij reuzenrassen kan dit worden uitgesteld tot een leeftijd van 2 jaar. De eerste loopsheid zou immers pas starten na het bereiken van een bepaald groeiniveau (cf. supra) en grote rassen groeien relatief trager dan kleine (Debraekeleer et al., 2000). Dit maakt dat het optreden van de eerste loopsheid afhankelijk is van de lichaamsgrootte. Zelfs binnen bepaalde rassen kan een zekere graad van variatie worden opgemerkt (Debraekeleer et al., 2000; Linde-Forsberg, 2001; Concannon, 2011).

\section{Interseksualiteit}

Mensen en dieren - en meer specifiek honden - met ambigue geslachtskenmerken, waarbij het vaak moeilijk is om vast te stellen of de hond nu een reu is of een teef, worden interseksen of hermafrodieten genoemd naar de Griekse god Hermaphroditos (Romagnoli en Schlafer, 2006). Het formuleren van een diagnostisch plan en het stellen van een correcte diagnose bij een interseks vereisen kennis van de normale seksuele ontwikkeling. Bij zoogdieren gebeurt deze ontwikkeling in drie opeenvolgende stappen: het vastleggen van het chromosomale geslacht, het ontstaan van het gonadale geslacht en het ontwikkelen van het fenotypische geslacht. Het welslagen van elk van deze stappen is noodzakelijk voor het bereiken van een normaal geslacht (Parker et al., 1999; Wernham en Jerram, 2006; Lyle, 2007; Meyers-Wallen, 2009; Poth et al., 2010).

Afwijkingen in het chromosomale, gonadale of fenotypische geslacht leiden tot de simultane aanwezigheid van mannelijke en vrouwelijke inwendige en/of uitwendige geslachtsorganen of tot de aanwezigheid van tweeslachtige of hypoplastische uitwendige geslachtsorganen (Romagnoli en Schlafer, 2006).

Aneuploïdie bij de hond (een aantal chromosomen dat afwijkt van 78), van het X-chromosoom veroorzaakt bij de hond eerder onderontwikkelde dan tweeslachtige geslachtsorganen (Poth et al., 2010). Hoewel het XXY-syndroom (klinefeltersyndroom bij de mens) meestal beschreven wordt als een afwijking die voorkomt bij fenotypisch mannelijke honden (of reuen) met hypoplastische testes zonder spermatogenesis (Romagnoli en Schlafer, 2006), werd deze chromosomale afwijking ook al gediagnosticeerd bij een fenotypisch vrouwelijke Deense dog met afolliculaire ovaria (Poth et al., 2010). Een nieuwe nomenclatuur voorgesteld door Poth et al. (2010) maakt daarom een indeling in 'testiculair XXY-syndroom' respectievelijk 'ovarieel XXY-syndroom'.

Bij afwijkingen van het gonadale geslacht is de chromosomale geslachtsconstitutie niet in overeenstemming met het gonadale geslacht van de hond. $X X$ 

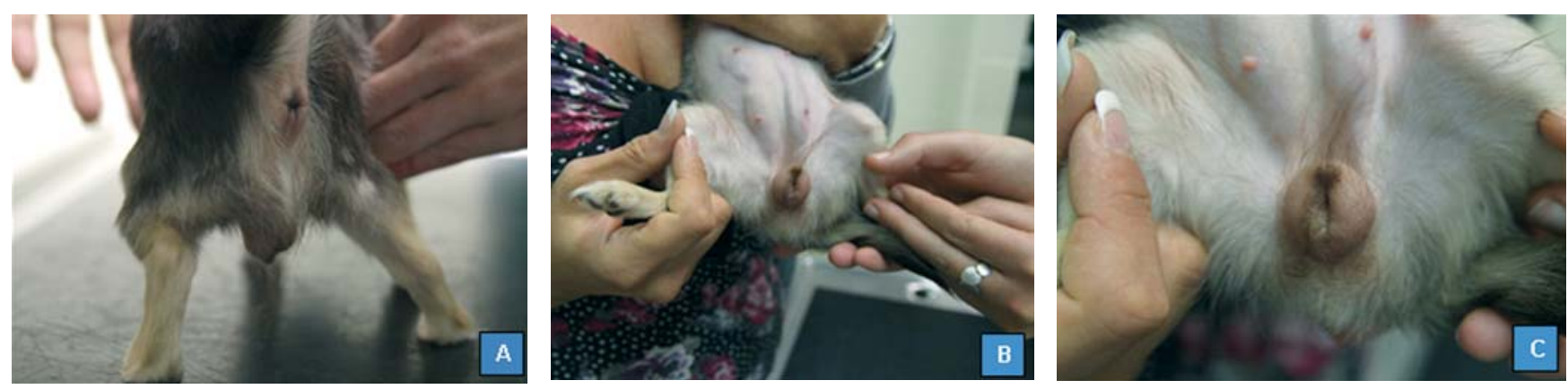

Figuur 2. Het initiële consult. A. vergrote, naar ventraal verplaatste vulva, $B$. vergrote vulva en sterk opgezette inguinale en caudaal abdominale melkklieren, $C$. detailopname: vergrote vulva en sterk opgezette inguinale melkklieren.

sex reversed honden zijn teven op basis van hun 78 , XX-karyotype, maar door de aanwezigheid van hetzij ovarieel en testiculair weefsel, hetzij enkel testiculair weefsel, wijzigt dit besluit. In het eerste geval wordt de hond geclassificeerd als een XX-ware hermafrodiet, in het laatste geval als een XX-reu (op basis van het gonadale geslacht). In het algemeen wordt de diagnose van waar hermafroditisme gesteld door een histopathologisch onderzoek van de gonaden uit te voeren na castratie van de hond. Een ware hermafrodiet heeft dus tenminste één ovotestis ofwel één ovarium en één testis (het zogenaamd lateraal hermafroditisme). Een XXreu blijkt daarentegen in het bezit te zijn geweest van bilaterale testes. In een overzichtsartikel vermeldden Poth et al. (2010) twee zeldzame gevallen van XY sex reversed honden (een fox terriër en een yorkshire terriër) met lateraal hermafroditisme. Bij de Amerikaanse cocker spaniël is XX sex reversal een erfelijke aandoening met een autosomaal recessief overervingspatroon (Meyers-Wallen en Patterson, 1988).

Bij afwijkingen van het fenotypische geslacht is het chromosomale en gonadale geslacht in overeenstemming, doch het geslacht op basis van het karyotype en de gonaden is gedeeltelijk in tegenstrijd met het fenotypische geslacht dat 'ambigu' of tweeslachtig is. Een mannelijke pseudohermafrodiet is aldus een reu op basis van zijn $78 \mathrm{XY}$-karyotype en het bezit van bilaterale testes, doch bij inspectie van deze hond kan men ook karakteristieken van een teef opmerken. Typisch voor pseudohermafroditisme is dus de aanwezigheid van mannelijke en vrouwelijke uitwendige geslachtsorganen. Mannelijk pseudohermafroditisme komt meer voor dan vrouwelijk pseudohermafroditisme. De oorzaak is ofwel het falen van de regressie van de Müllerse gangen (persistent Müllerian duct syndrome, PMDS), ofwel het mislukken van de androgeenafhankelijke masculinisatie, hetzij door enzymdeficiënties in de biosynthese van androgenen (deficiëntie $5 \alpha$-reductase bij de mens), hetzij door ongevoeligheid van androgeenreceptoren voor hun liganden in de targetweefsels $(X$-linked testicular feminisation syndrome bij de mens en knaagdieren) (Poth et al., 2010). Genetische defecten in Müllerian inhibiting substance (MIS) of diens receptor (MISRII) werden geïdentificeerd bij humane patiënten met PMDS. De stamboomanalyse van aangetaste families van miniatuur schnauzers in de VS onthulde een autosomaal recessief overervingspatroon. Recentelijk werd het oorzakelijke genetische defect van dit ras ontdekt: een enkelvoudige basenpaarmutatie in het MIS-type IIreceptor (MISRII) gen. Deze enkelvoudige basenpaarsubstitutie introduceert een stopcodon in exon 3. De homozygote mutatie beëindigt de translatie bij 80 aminozuren (Wu et al., 2009). Uiteraard heeft de homozygote mutatie enkel implicaties voor mannelijke individuen: het is dus een geslachtsgelimiteerde aandoening. In 2009 werd overigens een moleculaire diagnostische test ter opsporing van aangetaste PMDSreuen en van dragerreuen en -teven voorgesteld en goedgekeurd voor gebruik (Pujar en Meyers-Wallen, 2009). Vrouwelijk pseudohermafroditisme is meestal het gevolg van de toediening van progestagenen/androgenen aan de drachtige teef tijdens kritieke fasen van de seksuele ontwikkeling. Dit resulteert in de virilisatie van de vrouwelijke embryo's. Andere onderliggende oorzaken, zoals het adrenogenitaal syndroom (congenitale bijnierhyperplasie, i. e. een congenitaal erfelijk defect in de cortisolsynthese met een overproductie van androgenen tot gevolg (Ganong, 2005b)) bij vrouwen, werden nog niet aangetoond bij de hond. de Rooster et al. (2006) rapporteerden als enigen een casus over waar hermafroditisme bij zes vrouwelijke nestgenootjes na de toediening van synthetische androgenen aan een drachtige Amerikaanse staffordshire terriër teef.

\section{CASUSBESPREKING}

\section{Presentatie van de casus}

Een vrouwelijke intacte chihuahua van 10 weken oud werd bij de lokale dierenarts aangeboden met een vergrote vulva en met de klacht dat het hondje reeds vanaf de leeftijd van 9-10 weken seksueel gedrag vertoonde, met name rijgedrag op een speelgoedbeer. Toen het hondje 6 weken later op consultatie kwam in de kliniek van de vakgroep Voortplanting, Verloskunde en Bedrijfsdiergeneeskunde, Faculteit Diergeneeskunde, Universiteit Gent waren bovengenoemde klachten nog steeds aanwezig. Verder vertoonde het hondje sinds een tweetal weken sterk opgezette melkklieren.

Uit de anamnese konden geen afwijkend plasgedrag noch tekenen van pijn of ongemak worden afgeleid. De pup ondervond volgens de eigenares geen hinder van bovengenoemde klachten. Bovendien was het hondje erg speels en, afgezien van de klachten, volledig gezond. Er werd geïnformeerd naar de gezondheidstoestand van de nestgenoten. Bij de twee andere pups 
van hetzelfde nest (een reu en een teef) waren er geen klachten. Van een eventuele hormonale behandeling van het moederdier tijdens de dracht was overigens niets bekend. Ondanks het feit dat de pup niet behandeld werd met oestrogenen, kon het hondje toch dagelijks in contact komen met oestrogene hormonen via de huid van de eigenares (secundaire blootstelling). Zij bracht tweemaal daags oestradiolgel (Oestrogel $\AA$, Besins) aan op de schouders en het gezicht omwille van menopauzeklachten. Deze therapie volgde de eigenares reeds een zestal maanden.

Op algemeen klinisch onderzoek werden geen afwijkingen gevonden. Bij uitwendige inspectie (Figuur $2 \mathrm{~A}, \mathrm{~B}$ en $\mathrm{C}$ ) werd een enigszins naar ventraal verplaatste, vergrote vulva geobserveerd. Vaginale uitvloeiing was afwezig. Bij palpatie leek de clitoris niet vergroot te zijn. Exteriorisatie van de clitoris was niet mogelijk. De melkklieren gaven een sterk gezwollen indruk bij inspectie en palpatie. Vaginale cytologie toonde verhoornde cellen, grote intermediaire cellen, weinig leukocyten en geen rode bloedcellen. Dit beeld duidt op oestrogeneninvloed. Echografie van de bijnieren en de uterus bracht geen abnormaliteiten aan het licht. De ovaria leken wel iets vergroot te zijn.

\section{Differentiaaldiagnose en diagnostisch plan}

Uit de anamnese werd afgeleid dat de chihuahuateef dagelijks in contact kon komen met oestrogenen (OestroGel $($ ) ) via de huid van de eigenares. Het actieve bestanddeel van deze transdermale gel is oestradiol. In een klinische studie met gezonde postmenopauzale vrouwen werd bij het aanraken van de applicatieplaats gedurende 15 minuten, 1 uur na het aanbrengen van de gel, geen gevaar voor opname van oestradiol na secundaire blootstelling geobserveerd (Ascend Therapeutics, 2009a). Deze mogelijkheid mag echter niet afgeschreven worden. In het voorliggende geval was er waarschijnlijk een overdracht naar een kleine hond die bovendien de gel kon oplikken. Deze orale opname lijkt als transfermethode logischerwijze veel effectiever te zijn dan de transdermale weg, bestudeerd bij de gezonde postmenopauzale vrouwen van de voorgenoemde studie. Een mogelijke differentiaaldiagnose is bijgevolg gonadotropineonafhankelijke (perifere) vroegtijdige puberteit (of vroegtijdige pseudopuberteit). De term perifere puberteit (gedefinieerd als gonadotropineonafhankelijk) kan bijna altijd als synoniem gebruikt worden voor de term pseudopuberteit (gedefinieerd als het optreden van steroïdgenesis zonder gametogenesis) (Ganong, 2005a; Rasier et al., 2006). Met het lijstje van mogelijke etiologieën bij de mens in het achterhoofd (Tabel 1), lijkt abdominale echografie het meest aangewezen als diagnostisch hulpmiddel. Gezien zowel de ovaria als de bijnieren van de pup met deze beoordelingstechniek als normaal werden beoordeeld en de genetische oorzaken en primaire hypothyroïdie - Van Wyk and Grumbach Syndrome bij de mens (Durbin et al., 2011) - buiten beschouwing gelaten, blijft nog slechts één mogelijke oorzaak over, namelijk de exogene opname van oes- trogenen. In deze casus betreft het hoogstwaarschijnlijk een secundaire blootstelling via de huid van de eigenares.

Een tweede differentiaaldiagnose is interseksualiteit. Uit de anamnese bleek dat de twee andere pups van hetzelfde nest (een reu en een teef) geen klachten vertoonden. Deze specifieke vraag is belangrijk omdat een hormonale behandeling van het moederdier tijdens de dracht met progestagenen/androgenen kan leiden tot vrouwelijk pseudohermafroditisme. Het feit dat de pup in deze casus geen vergrote clitoris vertoonde, en dat er bij de vrouwelijke nestgenoot geen klachten waren, maakt deze mogelijkheid echter zeer onwaarschijnlijk. Andere vormen van interseksualiteit kunnen echter niet onmiddellijk worden uitgesloten en vereisen histopathologisch onderzoek van de gonaden na castratie, het beste in combinatie met karyotypering en eventueel genetische testen en/of een stamboomanalyse.

\section{Behandelplan en opvolging}

Gezien het sterke vermoeden van secundaire blootstelling aan oestrogenen, werd de eigenares geadviseerd om bij het aanbrengen van de oestradiolgel handschoenen te dragen en het contact met de pup zoveel mogelijk te vermijden. Er werd afgesproken het resultaat van deze therapie na één maand te evalueren bij de lokale dierenarts. Indien geen beterschap zou zijn opgetreden na deze periode, zou ovariohysterectomie de volgende aangewezen stap zijn in combinatie met histopathologisch onderzoek van de gonaden op abnormaliteiten. Hiermee zou waar hermafroditisme uitgesloten kunnen worden, hetgeen kadert binnen interseksualiteit.

$\mathrm{Na}$ één maand preventieve maatregelen waren de melkklieren van het hondje volgens de eigenares iets verkleind, de vulva leek echter nog steeds in dezelfde mate vergroot te zijn. De eigenares was reeds één week

Tabel 1. Etiologie van gonadotropineonafhankelijke (perifere) vroegtijdige puberteit bij de mens (classificatie volgens Brito et al., 2008; Eugster, 2009).

\section{Exogene toediening van sekssteroïden \\ Tumoren \\ Bijniertumoren (adrenocorticale tumoren) \\ Testistumoren (leydigceltumoren) \\ Ovariumtumoren (granulosaceltumoren)}

\section{Autonome ovariële cysten}

Ernstige, lange tijd onbehandelde, primaire hypothyroïdie

Genetische oorzaken

Gain-of-function mutaties in het GNAS1 gen (McCune-Albright syndroom) (ㅇ)

Gain-of-function mutaties in het LH-receptor gen (testotoxicosis) $(\hat{\jmath})$ 
overgeschakeld op een nieuwe therapie (oestradiol $0,5 \%$ liposomale gel, progesteron $10 \%$ liposomale gel, hydrocortisone $5 \%$ liposomale gel) en smeerde de gel op de buik. De lokale dierenarts vond dat de melklijsten zich mogelijk nog verder ontwikkeld hadden en dat de vulva nog steeds niet in grootte was afgenomen. De eigenares dacht eraan het hondje te laten steriliseren (ovariohysterectomie) omwille van de persisterende klachten. Vooraleer hiermee door te gaan werd aangeraden vooraf een radiografie te laten maken van de groeiplaten om de uiteindelijke schofthoogte van de hond te kennen. Oestrogenen brengen maturatie of de sluiting van de epifysen teweeg. Er werd medegedeeld dat meer geduld nodig zou kunnen zijn om effect te zien. Immers, in de literatuur wordt gynaecomastie bij drie prepuberale jongens vermeld door een secundaire blootstelling aan oestrogenen via contact met de huid van hun moeders. Elke moeder smeerde een gel op basis van geconcentreerde oestrogenen. Pas vier maanden na het volledig stopzetten van deze topicale applicatie, verminderde de gynaecomastie en normaliseerden de oestradiolniveaus (Felner en White, 2000).

Ongeveer twee maanden na het eerste consult kwam de chihuahuapup terug naar de kliniek. Bij inspectie waren de melkklieren duidelijk veel minder opgezet en ook de vulva was zichtbaar verkleind. Ook de ventrale verplaatsing van de vulva was verdwenen. Volgens de eigenares was er een opmerkelijke verbetering opgetreden gedurende de laatste paar weken. Het hondje was nog niet gesteriliseerd, waardoor het effect dus enkel toe te schrijven was aan de preventie van de secundaire blootstelling aan oestrogenen.

Vier maanden na het eerste consult rapporteerde de eigenares telefonisch een gunstige evolutie met het volledig verdwijnen van de initiële klachten.

\section{DISCUSSIE}

Ondanks het feit dat er slechts weinig gelijkaardige klinische cases gerapporteerd zijn bij honden, lijkt deze overdracht van oestradiol (of oestrogenen in het algemeen) toch een reëel gezondheidsrisico te vormen voor kleine gezelschapsdieren. Dit lijkt ook logisch. Er werden immers al meer cases beschreven bij kinderen die, net als kleine huisdieren, door hun kleiner distributievolume veel gevoeliger zijn voor het effect van de overdracht. In de veronderstelling dat ook kindjes oestrogenen eerder oraal opnemen door met de handjes in de mond te zitten na eventueel huidcontact, is de situatie met honden (en katten) vergelijkbaar. Als dierenarts is het belangrijk zich bewust te zijn van deze problematiek, zodat bij de presentatie van patiënten met dergelijke klachten adequaat kan worden ingegrepen en de beschreven differentiaaldiagnose in acht wordt genomen.

De dierenarts kan ook een stap verder gaan door preventief te handelen met een duidelijke en goede communicatie naar de eigenaars toe. Pups en kittens alsook kleine honden- en kattenrassen kunnen beschouwd worden als een risicogroep en kennis van substitutietherapie met oestrogenen bij vrouwelijke gezinsleden kan problemen helpen voorkomen. Substitutietherapie met oestrogenen is courant in de behandeling van postmenopauzale klachten. Naarmate het aantal aangegeven gevallen toeneemt, zal de farmaceutische industrie zich mogelijk engageren voor verder onderzoek, o.a. klinische studies naar de overdracht bij kinderen en huisdieren. Om een goede follow-up van de situatie te garanderen moet de dierenarts aan de bevoegde instanties rapporteren.

In Amerika werd op 29 juli 2010 door de FDA (Food and Drug Administration, VS) een waarschuwingsbericht verspreid betreffende Evamist ${ }^{\mathrm{TM}}$ : "keep kids, pets away from skin sprayed with Evamist". Dit product bevat het hormoon oestradiol en wordt op de binnenkant van de voorarmen aangebracht, tussen ellebogen en polsen, ter behandeling van postmenopauzale klachten bij vrouwen. De gerapporteerde neveneffecten bij kinderen zijn tepelzwelling, borstontwikkeling en vroegtijdige pseudopuberteit bij meisjes en borstvergroting bij jongens. Twee gevallen van secundaire blootstelling aan Evamist ${ }^{\mathrm{TM}}$ bij gesteriliseerde teven werden gerapporteerd aan het FDA's Center for Veterinary Medicine sinds 2007. De ene teef vertoonde tepel- en melkklierzwelling, vulvazwelling en leverfalen, de andere vaginaprolaps en een verhoogde oestrogenenconcentratie. In beide cases gebeurde de overdracht door het likken aan de armen van het baasje ter hoogte van de applicatieplaats (FDA Consumer Health Information, 2010; Voelker, 2010).

Rapporteren is dus belangrijk, enkel dan kunnen de bevoegde instanties de boodschap overbrengen naar het grote publiek. Na raadpleging van de wetenschappelijke literatuur werd slechts één gelijkaardig geval gevonden (Beziade, 2003). Ook hier betrof het een gesteriliseerde teef, maar dit maal met als voornaamste klacht alopecia. Opmerkelijk is dat de overdracht eveneens te wijten zou zijn geweest aan Oestrogel ${ }^{\circledR}(\mathrm{Be}-$ sins). Er werd echter nog geen enkel waarschuwingsbericht betreffende deze gel gevonden. De 'patient information' folder vermeldt enkel: "It is important that you do not spread the medicine to others, especially men and children. Be sure to wash your hands after applying EstroGel. Do not allow others to make contact with the area of skin where you applied the gel for at least 1 hour after application" (Ascend Therapeutics, 2009b). Kleine gezelschapsdieren worden echter niet vernoemd.

Voor zo ver de auteurs bekend, is dit het eerste geval van vroegtijdige perifere puberteit ten gevolge van exogene oestrogenen. De andere vermelde differentiaaldiagnose, interseksualiteit, is als problematiek voldoende bekend bij de dierenartsen, maar was in het onderhavig geval zo goed als uit te sluiten. Aangezien het gebruik van een oestrogenengel een vaak voorkomende behandeling is bij menopauzeklachten bij de vrouw, dient bij een geval van hyperoestrogenisme bij de hond of kat (vroegtijdige pseudopuberteit, patroonalopecia (Vandenabeele et al., 2010), pancytopenie (De Bosschere en Deprest, 2010), etc.) oestrogenenbehandeling ook steeds in de anamnese vermeld te worden. 


\section{REFERENTIES}

Ascend Therapeutics (2009a). Potential for estradiol transfer and effects of washing. http://www.estrogel.com/ PDFs/EstroGel-Prescribing-Info.pdf, p. 5.

Ascend Therapeutics (2009b). What should I avoid while using EstroGel? http://www.estrogel.com/PDFs/EstroGel-Patient-Info.pdf, p. 4-5.

Beziade O. (2003). Alopécie associée à l'ingestion d'oestradiol chez une chienne. Pratique Médicale et Chirurgicale de l'Animal de Compagnie 38, 327-332.

Brito V. N., Latronico A. C., Arnhold I. J. P., Mendonça B. B. (2007). Update on the etiology, diagnosis and therapeutic management of sexual precocity. Arquivos Brasileiros de Endocrinologia \& Metabologia 52, 18-31.

Concannon P. W. (2011). Reproductive cycles of the domestic bitch. Animal Reproduction Science 124, 200-210.

De Bosschere H., Deprest C. (2010). Estrogen-induced pancytopenia due to a Sertoli cell tumor in a cryptorchid Beauceron. Vlaams Diergeneeskundig Tijdschrift 79, 292-296.

de Rooster H., Vercauteren G., Görtz K., Saunders J., Polis I., Rijsselaere T. (2006). True hermaphroditism in six female littermates after administration of synthetic androgens to a pregnant bitch. Reproduction in Domestic Animals 41, 22-26.

Debraekeleer J., Gross K. L., Zicker S. C. (2000). Normal dogs. In: Hand M. S., Thatcher C. D., Remillard R. L. en Roudebush P. (editors). Small Animal Clinical Nutrition. $4^{\text {th }}$ Edition, Walsworth Publishing Company, Marceline, Missouri, p. 211-260.

Durbin K. L., Diaz-Montes T., Loveless M. B. (2011). Van Wyk and Grumbach syndrome: an unusual case and review of the literature. Journal of Pediatric and Adolescent Gynecology 24, 93-96.

Eugster E. A. (2009). Peripheral precocious puberty: causes and current management. Hormone Research 71, 64-67.

FDA Consumer Health Information (2010). Keep kids, pets away from skin sprayed with Evamist.http://www.fda. gov/downloads/ForConsumers/ConsumerUpdates/UCM2 20544.pdf, p. 1.

Felner E. I., White P. C. (2000). Prepubertal gynecomastia: indirect exposure to estrogen cream. Pediatrics 105, 5557.

Ganong W. F. (2005a). The gonads: development \& function of the reproductive system. In: Review of Medical Physio$\operatorname{logy} .22^{\text {nd }}$ Edition, Large Medical books/McGraw-Hill, United States, p. 411-453.

Ganong W. F. (2005b). The adrenal medulla \& adrenal cortex. In: Review of Medical Physiology. $22^{\text {nd }}$ Edition, Large Medical books/McGraw-Hill, United States, p. 356-381.

Johnston S. D., Root Kustritz M. V., Olson P. N. S. (2001). The canine estrous cycle. In: Kersey R. en LeMelledo D. (editors). Canine and Feline Theriogenology. $1^{\text {st }}$ Edition, W. B. Saunders Company, Philadelphia, p. 16-31.

Linde-Forsberg C. (2001). Biology of reproduction and modern reproductive technology. In: Ruvinsky A. en Sampson J. (editors). The Genetics of the Dog. $1^{\text {st }}$ Edition, CABI Publishing, Oxon / New York, p. 401-430.

Lyle S. K. (2007). Disorders of sexual development in the dog and cat. Theriogenology 68, 338-343.

Lyon M. F. (1999). X-chromosome inactivation. Current Biology 9, 235-237.

Maeda K., Ohkura S., Uenoyama Y., Wakabayashi Y., Oka Y., Tsukamura H., Okamura H. (2010). Neurobiological mechanisms underlying GnRH pulse generation by the hypothalamus. Brain Research 1364, 103-115.
Meyers-Wallen V. N. (2009). Review and update: genomic and molecular advances in sex determination and differentiation in small animals. Reproduction in Domestic Animals 44, 40-46.

Meyers-Wallen V.N., Patterson D.F. (1988). XX sex reversal in the American cocker spaniel dog: phenotypic expression and inheritance. Human genetics, 80, 23-30.

Nishihara M., Takeuchi Y., Tanaka T., Mori Y. (1999). Electrophysiological correlates of pulsatile and surge gonadotrophin secretion. Reviews of Reproduction 4, 110-116.

Parker K. I., Schedl A., Schimmer B. P. (1999). Gene interactions in gonadal development. Annual Review of Physiology 61, 417-433.

Poth T., Breuer W., Walter B., Hecht W., Hermanns W. (2010). Disorders of sex development in the dog - Adoption of a new nomenclature and reclassification of reported cases. Animal Reproduction Science 121, 197-207.

Pujar S., Meyers-Wallen V. N. (2009). A molecular diagnostic test for persistent müllerian duct syndrome in miniature schnauzer dogs. Sexual Development 3, 326-328.

Rasier G., Toppari J., Parent A.-S., Bourguignon J.-P. (2006). Female sexual maturation and reproduction after prepubertal exposure to estrogens and endocrine disrupting chemicals: A review of rodent and human data. Molecular and Cellular Endocrinology 254-255, 187-201.

Rehm S., Stanislaus D. J., Williams A. M. (2007). Estrous cycle-dependent histology and review of sex steroid receptor expression in dog reproductive tissues and mammary gland and associated hormone levels. Birth Defects Research. Part B, Developmental and reproductive toxicology 80, 233-245.

Romagnoli S., Schlafer D. H. (2006). Disorders of sexual differentiation in puppies and kittens: a diagnostic and clinical approach. Veterinary Clinics of North America: Small Animal Practice 36, 573-606.

Schmidt-Küntzel A., Nelson G., David V. A., Schäffer A. A., Eizirik E., Roelke M. E., Kehler J. S., Hannah S. S., O'Brien S. J., Menotti-Raymond M. (2009). A domestic cat X chromosome linkage map and the sex-linked orange locus: mapping of orange, multiple origins and epistasis over nonagouti. Genetics 181, 1415-1425.

Sisk C. L., Foster D. L. (2004). The neural basis of puberty and adolescence. Nature Neuroscience 10, 1040-1047.

Terasawa E., Fernandez D. L. (2001). Neurobiological mechanisms of the onset of puberty in primates. Endocrine Reviews 22, 111-151.

Vandenabeele S., Van Goethem B., de Rooster H. (2010). Patroonalopecia ten gevolge van cysteuze ovaria bij een bouvier. Vlaams Diergeneeskundig Tijdschrift 79, 389393.

Voelker R. (2010). Estrogen spray poses risks to children, pets through contact with treated skin. American Medical Association 304, 953.

Wernham B. G. J., Jerram R. M. (2006). Male pseudohermaphroditism in a Labrador Retriever, and a review of mammalian sexual differentiation. New Zealand Veterinary Journal 54, 248-252.

Wu X., Wan S., Pujar S., Haskins M. E., Schlafer D. H., Lee M. M., Meyers-Wallen V.N. (2009). A single base pair mutation encoding a premature stop codon in the mis type ii receptor is responsible for canine persistent müllerian duct syndrome. Journal of Andrology 30, 46-56. 


\title{
OFFICE VACCINOGÈNE CENTRAL DE L'ÉTAT
}

\author{
Anderlecht 1882
}

Omdat de productie van het pokkenvaccin uitgaande van menselijke stammen onvoldoende resultaat opleverde, werd in de tweede helft van de $19^{\text {de }}$ eeuw definitief overgeschakeld naar de bereiding van het pokkenvaccin op vaarzen. Hoewel het woord vaccin, afgeleid van koe (vacca) en koepokken (vaccinia), goed ingeburgerd was, bleven toch veel dokters lange tijd niet overtuigd van de superioriteit van Jenners uitvinding.

In België werd in 1868 een 'Institut pour la Production du Vaccin animal' opgericht dat zou instaan voor de productie en de verspreiding van dit type vaccin. In 1882 werd dit omgevormd tot het 'Office Vaccinogène Central de l'Etat' en overgebracht naar de Rijksveeartsenijschool te Cureghem (Anderlecht). In de toezichtcommissie zetelde onder meer Jules Bordet, de latere Nobelprijswinnaar van wie de naam Bordetella afgeleid is.

Het vaccin werd gewonnen op de afgeschoren huid van vaarzen en geoogst na slachting. Het is een methode die hedendaagse dierenbeschermers zou doen griezelen, maar die een ongelooflijk belangrijke bijdrage leverde

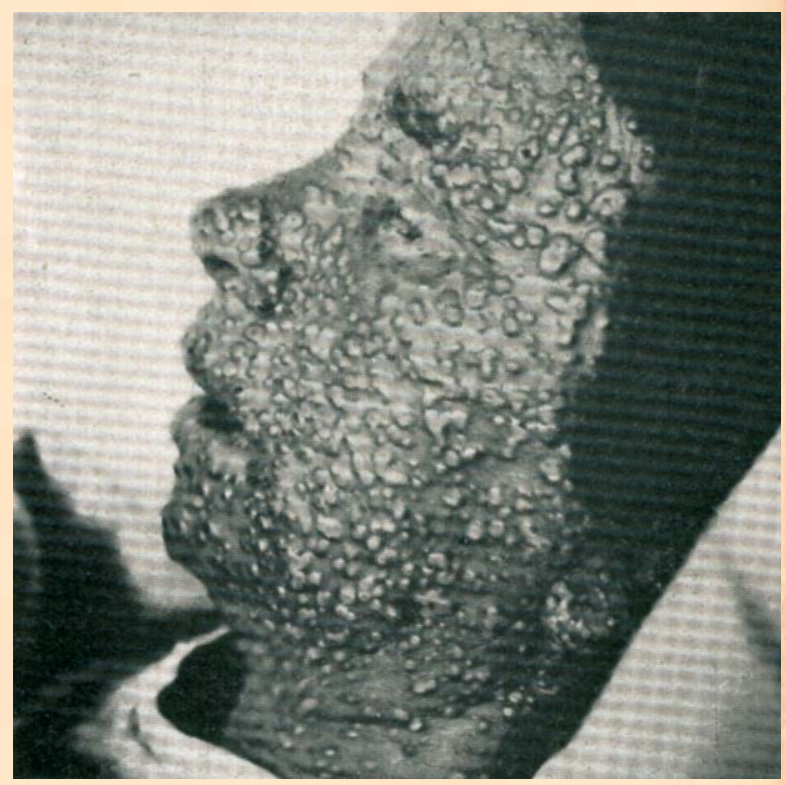
aan de bestrijding van deze gruwelijke ziekte en die uiteindelijk tot de uitroeiing ervan zou leiden.

De dienst leverde blijkbaar voorbeeldig werk. In 1883 produceerde het 'office' vaccins voor 44.863 mensen. Amper zes jaar later was het aantal doses gestegen tot 381.246, terwijl de kosten met 10\% daalden. Het

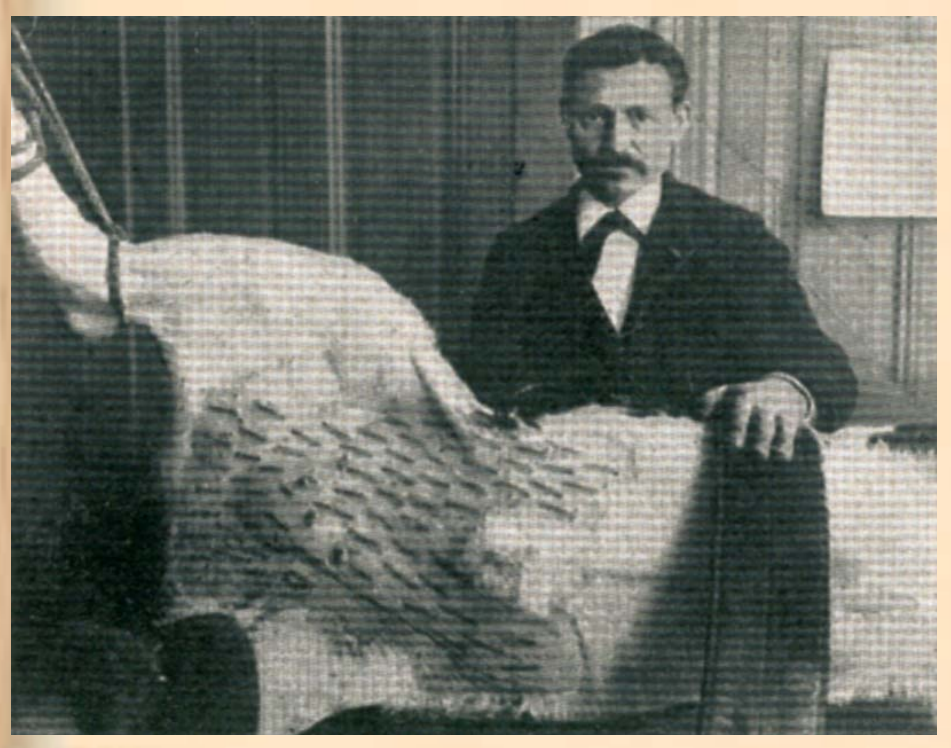
instituut bewees zijn nut onder meer tijdens een laatste pokkenepidemie in 1902 - 1903, toen ruim 30.000 doses per dag de deur uitgingen.

De vaccinatie werd op alle mogelijke manieren fel gepropageerd. Een voorstel tot verplichte pokkeninenting voor het eerst ingediend in 1902 en daarna meerdere keren opnieuw, werd echter op ideologische gronden telkens verworpen. Toen de enting in 1946 uiteindelijk verplicht werd, was de ziekte in ons land zo goed als verdwenen.

In de vakliteratuur wordt een grote rol toebedeeld aan de pokkenvaccinatie bij de verbetering van het imago van het artsenberoep tijdens de $19^{\text {de }}$ eeuw. De invloed van deze beroepsgroep steeg enorm en leidde zelfs tot wat genoemd wordt: de 'medicalisering van de samenleving'.

De afbeeldingen tonen een pokkenpatiënt met een milde (niet-coalescerende) vorm van pokken en een vaars gereed voor de oogst van het pokkenvaccin (Amsterdamse Pokkeninrichting).

Bron: Velle, K., De nieuwe biechtvaders. De sociale geschiedenis van de arts in België, Kritak, Leuven, 1991, p. $51-58$. 